\title{
14: 103058923-103055749
}

National Cancer Institute

\section{Source}

National Cancer Institute. 14: 103058923-103055749. NCI Thesaurus. Code C41968.

Physical location of CKB_Gene 